\title{
Environmental influence on cultivable microbial community in the sediment of Sundarban mangrove forest, India
}

\author{
Subhajit Das ${ }^{1 *}$, Minati $\mathrm{De}^{2}$, Tapan Kumar Jana ${ }^{1}$ and Tarun Kuma De ${ }^{1}$ \\ ${ }^{1}$ Department of Marine Science, Calcutta University, 35 B.C.Road, Kolkata -700019, WB, India. \\ ${ }^{2}$ Maniktala Siksha Bhavan, Calcutta, India.
}

Accepted 20 August, 2013

\begin{abstract}
In the Sundarban Mangrove forest, microbial activities are dominantly involved both in the mineralization and decomposition processes that regulate nutrient profile of sediment of different depth. It was found that besides changing the water and sediment quality, monsoonal cycle plays a crucial role to regulate microbial population distribution in the mangrove sediment. Statistical analysis revealed that organic carbon was the most significant factor that regulates the total microbial population. The cellulose degrading bacteria, [mean value of CFU $14.320 \times 10^{6}$ (gm dry weight of sediment) ${ }^{-1}$ ] was dominant throughout the year. The sulphate reducing bacteria showed an increasing trend along depth with a minimum value at the surface that is $6.113 \times 10^{6}$ ( $\mathrm{g}$ dry weight of sediment $)^{-1}$ and $12.312 \times 10^{6}$ (g dry weight of sediment) ${ }^{-1}$ at a depth of $60 \mathrm{~cm}$. Both rooted and deep mangrove forest regions showed distinct stratification of microbial population and nutrient distribution whereas the unrooted regions did not show any such stratification which may be attributed to frequent wave and tidal action that make it a higher energy zone. Intensification of monsoonal cycle could heavily affect microbe dominated sediment biogeochemistry and subsequent change in the regional ecology of Sundarban mangrove forest.
\end{abstract}

Key words: Sundarban Mangrove, microbial population, monsoonal cycle, nutrient concentration.

\section{INTRODUCTION}

Mangroves are highly productive marine ecosystem where bacteria actively participate in biomineralization and biotransformation of minerals (Gonzalez-Acosta et al., 2006). The distribution of microbial activities in estuarine systems is clearly complex and variable. Much research remains to be done in order to define the distributions of microbial activities and the major factors involved in controlling these distributions in estuaries. Leaves and wood provided by mangrove plants to the sediment are degraded primarily by large variety of microbes which actively participated in the heterotrophic food chain (Thatoi et al., 2012; Alongi et al., 1989, 1993; Alongi,1994). Major products of general recycling of organic matter are detritus which is rich in enzymes and proteins and contains large microbial population (Holguin et al., 2001). Bacteria are the major participants in the carbon, sulphur, nitrogen and phosphorous cycles in mangrove forest (Toledo et al.,1995, Vazquez et al., 2000; Rojas et al., 2001). Bacterial activity is responsible for most of the carbon recycling in mangrove sediment under both oxic and anoxic condition (Das and Dangar, 2008). Many species of phosphate solubilizing rhizosphere 
bacteria associated with black mangrove roots were found. The mechanism for phosphate solubilization probably involves the production of several organic acids (Vazquez et al., 2000).

Saprophytic fungi are fundamental to many aspects of decomposition and energy flow in mangrove forests (Nedwell, 1982; Radhakrishnan et al., 2011). Most investigation of anaerobic metabolism in natural ecosystem have dealt with sulfate rich marine sediments where sulfate reduction is the dominating process or eutrophic lake sediments where sulfate and nitrate is depleted in the hypolimnionn and in the superficial sediment layers leaving terminal carbon mineralization principally to methane producing bacteria (Sahoo and Dhal, 2009; Senior et al., 1982; Lovley and Klug, 1982). Sulfate reduction, methane production, and denitrification are the important processes for the terminal electron removal during decomposition of organic matter in anoxic environment. The methanogens are characterized by their ability to produce methane from hydrogen and carbon di oxide, formate, acetate, methanol, etc (Chen et al., 2010; Mohanraju and Natarajan, 1992). Methanotrophs are a subset of a physiological group of bacteria known as methylotrophs. They are unique in their ability to utilize methane as a source of carbon and energy (Liebner et al., 2008; Chen-rul et al., 2003). Nitrogen fixing bacteria are the other group of bacteria that are involved in formation of ammonia or organic nitrogen from atmospheric nitrogen. They may be free living or symbiotic in nature. It has been studied that $\mathrm{N}_{2}$ fixation by heterotrophic bacteria are generally regulated by specific environmental factors like oxygen, combined Nitrogen and the availability of carbon source for energy requirement (Teri and Mary, 2005). Aerobic, autotrophic nitrifiers oxidize ammonia to nitrite and nitrate, with molecular oxygen as electron acceptor (Nicol et al., 2008). Nitrite and nitrate are reduced to dinitrogen gas by heterotrophic denitrifying bacteria that use NO_x instead of oxygen as electron acceptor (Hayatsu et al., 2008; Riley et al., 1995).

The purpose of the present study was to examine seasonal and spatial variations in microbial population (bacteria and fungi) in mangrove soil and to find out the correlation between different microbes with nutrients.

\section{Study area}

Sundarban Mangrove forest is located geographically in between $21^{\circ} 31^{\prime} \mathrm{N}$ and $22^{\circ} 30^{\prime} \mathrm{N}$ and longitude $88^{\circ} 10^{\prime} \mathrm{E}$ and $89^{\circ} 51^{\prime} \mathrm{E}$ along the North East coast of Bay of Bengal, India. This mangrove forest is a part of the estuarine system of the River Ganges, NE coast of Bay of Bengal (Figure 1), which covers $9630 \mathrm{~km}^{2}$, out of which $4264 \mathrm{~km}^{2}$ of inter-tidal area, covered with thick mangroves, is subdivided as forest sub-ecosystem and 1781 $\mathrm{km}^{2}$ of water area as aquatic sub-ecosystem. The tide in this estuarine complex is semidiurnal in nature with spring tide range between 4.27 and $4.75 \mathrm{~m}$ and neap tide range between 1.83 and $2.83 \mathrm{~m}$. It is a unique bioclimatic zone in land ocean boundaries of Bay of Bengal and the largest delta on the globe. Several numbers of discrete islands constitute Sundarbans. One of these Islands, Lothian Island covering an area of $38 \mathrm{~km}^{2}$ has been notified as a sanctuary and is situated at the confluence of Saptamukhi River and Bay of Bengal. In the southern part of the island, the ground level is high while in the northern areas, the land is low and gets inundated during highest high tide. Mangroves, Avicennia alba, Avicennia marina and Avicennia officinalis are the dominant species, Excoecaria agallocha and Heritiera fomes are thinly distributed and Ceriops decandra is found scattered all over the island. The deltaic soil of Sundarban Biosphere Reserve comprises mainly with saline alluvial soil consisting of clay, silt, fine sand and coarse sand particles. It is described as very deep, poorly drained, fine soils occurring on level to nearly level lower delta with loamy surface, severe flooding and very strong salinity (extensive extent) associated with very deep, very poorly drained, fine loamy soil. Sediment samples were collected from different sites namely rooted, un-rooted and deep forest regions at Lothian Island to critically examine the spatial variations of depth integrated microbial diversity in these mangrove ecosystem.

\section{MATERIALS AND METHODS}

Sediment cores were collected aseptically using a hand -held stainless steel core sampler $(3.2 \mathrm{~cm}$ diameter, $100 \mathrm{~cm}$ long) from the different tidal zone of Sundarban Mangrove Forest and from different depth $(0-10,10-20,20-30,30-40,40-50,50-60 \mathrm{~cm})$ during pre-monsoon, monsoon and post monsoon. Samples were collected into sterilized container and were transferred to laboratory in iced condition for both chemical and microbiological assay. The three tidal zones were sediment from dense forest region, sediment from the region with pneumatophores near mid littoral zone (rooted), and the sediment from the lower littoral zone where no pneumatophores were found (un-rooted).

\section{Quantification of bacteria and fungi}

Sediment samples were stored at $4^{\circ} \mathrm{C}$ immediately after collection and transported to the laboratory, for analysis with adequate care. $10 \mathrm{~g}$ of sample from different depth of different regions were homogenized with sterilized phosphate buffer solution. Serial dilutions up to $10^{-4}$ were made and inoculation was done with 0.1 $\mathrm{ml}$. Quantification of bacteria and fungi from mangrove sediments was carried out by spread plate method for different type of bacteria such as phosphorous solubilising bacteria (PSB), cellulose degrading bacteria (CDB), nitrifying bacteria, free living nitrogen fixing bacteria and fungi and they were incubated at different condition (Ramanathan et al., 2008). Sulfate reducing bacteria was cultured in Starkey's medium in anaerobic condition (Fathul et al., 2008).

\section{Sediment quality measurement}

Sulphate, nitrite-nitrogen, nitrate-nitrogen, phosphate, silicate 


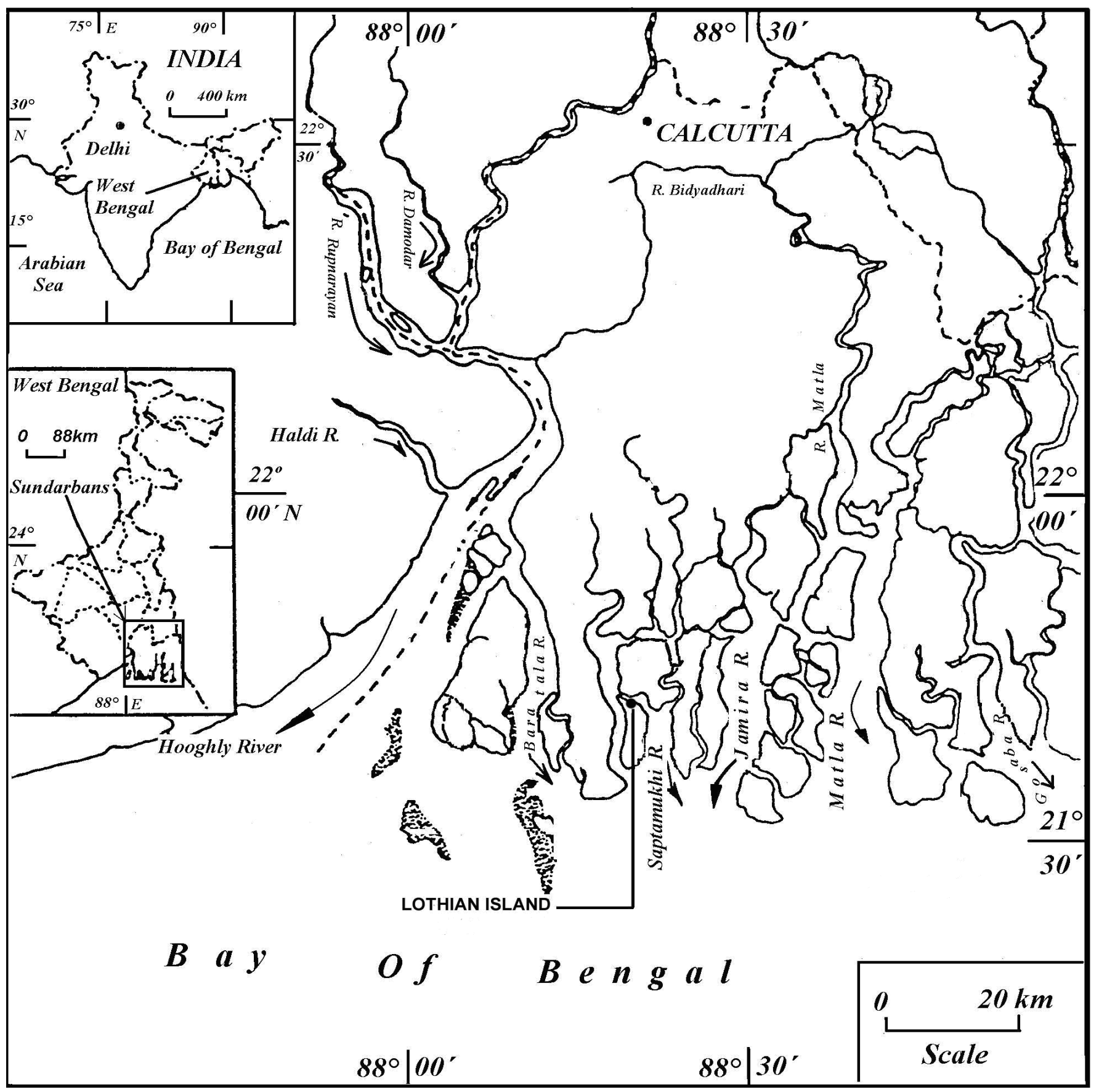

Figure 1. Map showing the location of study area

concentration of the sediment sample was measured at $10 \mathrm{~cm}$ interval (from 0 to $60 \mathrm{~cm}$ depth). $30 \mathrm{~g}$ of soil subsample was collected from the different depth and was immediately extracted in $75 \mathrm{~mL}$ of $2 \mathrm{~mol} \mathrm{~L}^{-1}$ potassium chloride $(\mathrm{KCl})$. The mixture was shaken until well mixed and allowed to stand overnight (Riley et al., 1995). After $24 \mathrm{~h}, 4 \mathrm{~mL}$ of the supernatant was collected for the estimation of different nutrients using standard spectrophotometric methods (Grasshoff, 1983). The $\mathrm{pH}$ value was measured in a 1:5 $(\mathrm{w} / \mathrm{w})$ soil water suspension using electric digital $\mathrm{pH}$ meter (Tiwari et al., 1989) and soil organic carbon was measured by standard methods (Walkley and Black, 1934).

\section{RESULTS AND DISCUSSION}

Mangrove sediment at Indian Sundarban showed seasonal variation with respect to both major nutrient concentrations and microbial population. Beside monsoonal addition of nutrients to the system mangrove, litters also played a significant role in regulating the nutrient status that in turn controls the microbial population (Das et al., 2012). Among several physical factors 
tidal inundation, wave action, presence of mangrove roots and bioturbation are the important factors considered for determining microbial abundance in the mangrove sediment from surface to a depth up to $60 \mathrm{~cm}$ (Laing et al., 2009; Bharathkumar et al., 2008). During premonsoon, nutrient concentration in soil sample of deep forest region showed very weak stratification from surface to $30 \mathrm{~cm}$ of depth with almost uniform distribution. Intense bioturbation up to $30 \mathrm{~cm}$ depth by several benthic organisms could cause uniform mixing of soil nutrients. No significant variation of silicate concentration was found throughout the entire depth.

Again silicate concentration was found to be more in unrooted and rooted region than that of deep forest region, because rooted and un-rooted region is at the nearest part of the river and the ultimate source of silicate is riverine system. Gradual decrease in organic carbon and phosphate-phosphorous concentration was observed from 30 to $60 \mathrm{~m}$. During transportation of organic matter from surface to bottom, it is decomposed by microbes. As a result, organic content of soil decreased with increasing depth (Kristensen et al., 2008). Organic carbon in the deep forest sediment was found to be more than that of rooted and un-rooted region. It could be attributed to mangrove litter fall with an annual rate of $1603 \mathrm{~g} \mathrm{~m}^{-2}$ year $^{-1}$ (Ghosh et al., 1990). Both rooted and un-rooted regions regularly experience significant tidal flushing which carried away significant amount of mangrove litter. In contrary, the deep forest seldom gets inundated by tidal water resulting to organic carbon rich sediment. In all the sediments, organic carbon was found maximum during monsoon followed by post monsoon and premonsoon (Figure 2a).

The microbial population was also found maximum in the deep forest sediment relative to the other two sites (Figure 2a). Nitrate-Nitrogen concentration was increased from surface to $40 \mathrm{~cm}$ of depth but decreased from 60 to $40 \mathrm{~cm}$. Vertical movement of materials, nutrient cycling and reuse driven by various burrowing organisms could have an effect on this nitrate-nitrogen distribution along the depth profile up to $40 \mathrm{~cm}$. Less abundance of bioturbation below $40 \mathrm{~cm}$ could enhance the anoxic condition which in turn initiate denitrification causing sudden depletion of nitrate-nitrogen. The nitrite-nitrogen concentration showed no significant variation throughout depth but slight increased below $50 \mathrm{~cm}$ of depth which may be an indication of denitrification. Population of SRB was found to be increased with increasing depth. The Eh value of surface soil and soil from $60 \mathrm{~cm}$ of depth was found to be $-78 \mathrm{mV}$ and $-163 \mathrm{mV}$ respectively. Thus, more anoxic condition preferred the more population of SRB in the bottom soil than that of surface soil (Brune et al., 2000; Sass et al., 1997). Fungal population showed decreasing trend with increasing depth. Freeliving nitrogen fixing bacterial population that showed from surface to $30 \mathrm{~cm}$ depth increased again from $30 \mathrm{~cm}$ to $50 \mathrm{~cm}$ of depth. After the death of plant, the woods are carried carried away by tidal action or consumed by herbivorous animal but the root that remains attached to the bottom soil below the $50 \mathrm{~cm}$ depth seldom may act as the source of corbon to fungus and cellulose degrading bacteria (Figure 2a).

During monsoon, nitrate-nitrogen organic carbon content of soil showed decreasig pattern along with decrease in population of nitrifying bacteria with increase in depth. Silicate concentration showed little variation with increasing depth. Population of PSB was found to decreased with increasing depth and at same time, phosphate-phosphorous concentration was also decreased with increase in depth. Population of CDB decreased with increas in depth as the organic carbon content of the soil was also decreased with increase in depth (Zemin et al., 2010). Population of SRB showed increase in trend as Eh value found in the surface and below $60 \mathrm{~cm}$ of depth were -83 $\mathrm{mV}$ and $-169 \mathrm{mV}$ (Figure 2b).

During postmonsoon, nitrate-nitrogen organic carbon content of soil showed decreasing pattern along with decrease in population of nitrifying bacteria with increase in depth. Silicate concentration showed little variation with increasing depth. Population of PSB was found to be decreasing with increasing depth and at a same time phosphate-phosphorous concentration was also decreased with increasing depth. Free living nitrogen fixing bacteria showed decrease in population upto $30 \mathrm{~cm}$ of depth but below $30 \mathrm{~cm}$ to the next $60 \mathrm{~cm}$ of depth their population was increased. Population of CDB decrased with increase in depth as the organic carbon content of the soil was also decreased with increase in depth. Sulfate concentration did not show distinct stratification though population of SRB showed increase in trend as Eh value was found on surface and below $60 \mathrm{~cm}$ of depth were $-87 \mathrm{mV}$ and $-198 \mathrm{mv}$ (Figure 2c).

In the region of pneumatophores or rooted region during pre-monsoon, organic carbon content of soil showed decreasing pattern along with decrease in population of CDB from surface to $30 \mathrm{~cm}$ of depth and from $30 \mathrm{~cm}$ to the next $60 \mathrm{~cm}$ of depth, reverse image was found. Same profile was found for population of PSB and Phosphate-Phosphorous concentration. Silicate concentration showed little variation with increasing depth. Free living nitrogen fixing bacteria showed no gradiation along the deph. Sulfate concentration did not show distint stratification though population of SRB showed increase in trend as Eh value was found to surface and below $60 \mathrm{~cm}$ of depth were $-89 \mathrm{mV}$ and -198 $\mathrm{mV}$ (Figure 3a). Other nutrient and microbial population showed little gradiation along the depth. This may be due to perforation of soil because of presence of pneumatophores (Figure 3a).

During monsoon season, sediment of rooted region showed more or less uniform distribution of nutrients along depth profile. During that season, effective tidal force becomes more active to mix up the nutrients vertically. Sulfate concentration increased suddenly at 

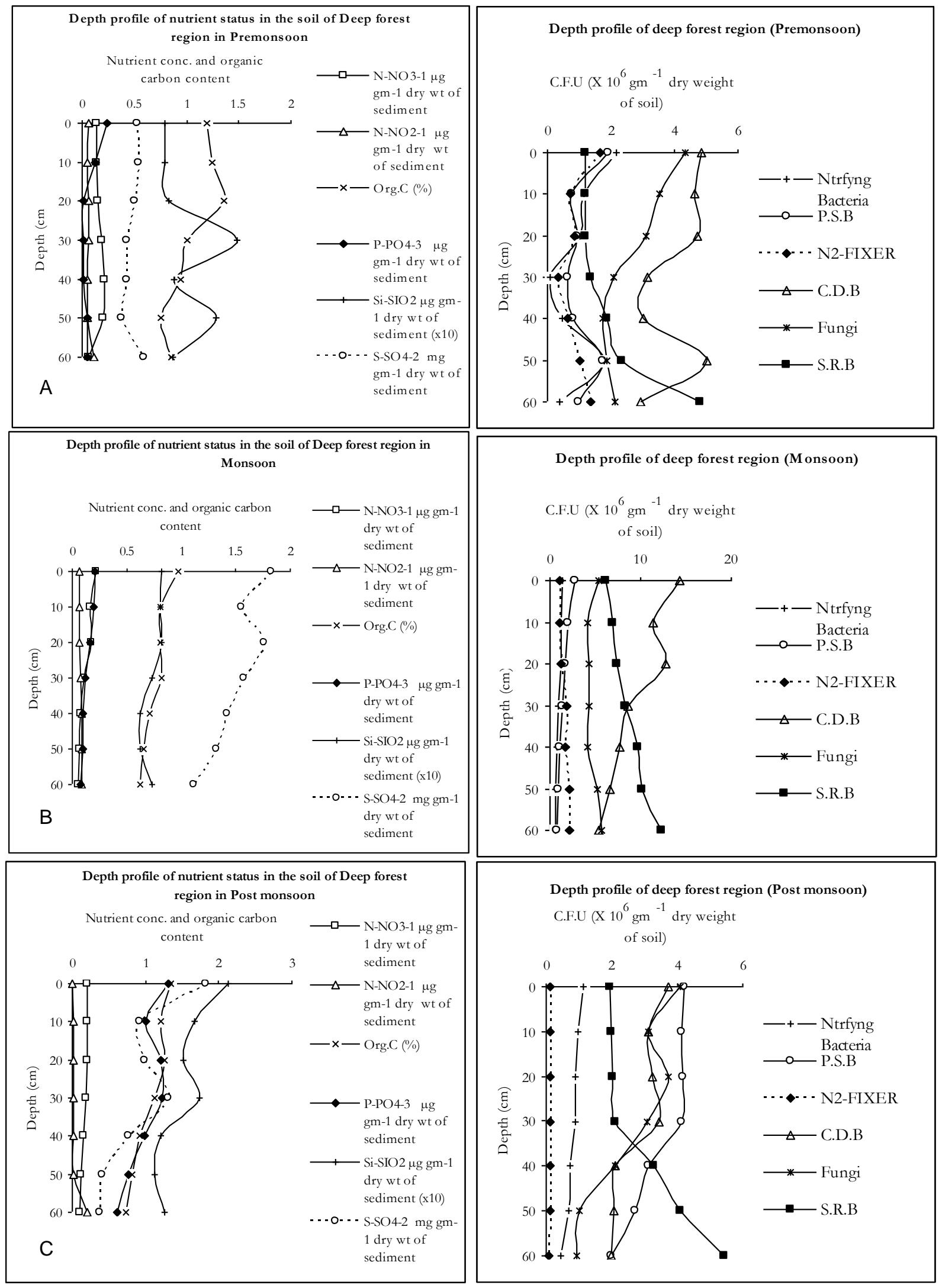

Figure 2. Graphical representation of deep forest region that shows profile of nutrient concentration and CFU of microbes of different category along depth profile during during pre monsoon (a), monsoon (b) and post monsoon (c) respectively. 


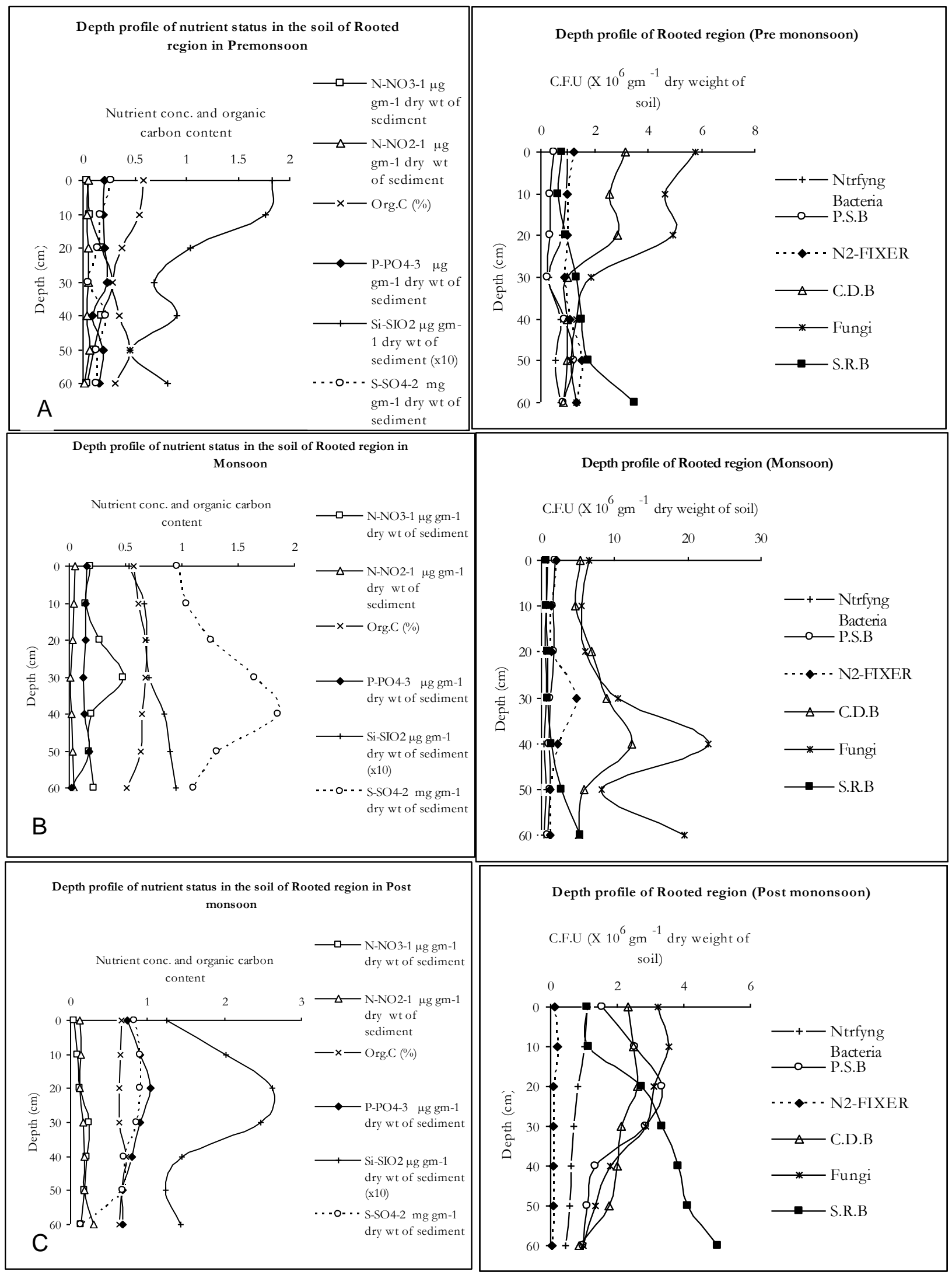

Figure 3. Graphical representation of rooted region that shows profile of nutrient concentration and CFU of microbes of different category along depth profile during during pre monsoon (a), monsoon (b) and post monsoon (c) respectively. 
about $40 \mathrm{~cm}$ and it may be due to sudden intrution of inorganic sulfate from remote environment. Again C.F.U of SRB showed increase in their population from 30 to 50 $\mathrm{cm}$ of depth. Same type of trend was also found for population of fungus and CDB. It may be due to accumulation of such group of bacteria through the pores present in that zone (Figure 3b).

During postmonsoon, uniformity of nutrient concentration was found with increase in depth. Random change in silicate concentration was found along depth profile. Same time, fungal population, population of cellulose decomposing bacteria and population of nitrifying basteria showed decreasing pattern with increasing depth. Free living nitrogen fixing bacteria showed more or less same population with increasing depth. Population of sulfate reducing bacteria was found to be increased with increase in depth (Figure 3c).

During pre-monsoon sulfate concentration was found to decrease with increasing depth followed by gradual increase of CFU of sulfate reducing bacteria. This may be due to more anoxic condition which is evident from sediment decreasing Eh value with increasing depth (Feng et al., 2003). Eh value was found maximum and minimum at the surface and $60 \mathrm{~cm}$ depth of un-rooted region with a value of $-64.7 \mathrm{mV}$ and $-116.9 \mathrm{mV}$, respectively. Nitrite concentration did not vary with depth profile. Phosphate, nitrate, organic carbon content was found to show no proper gradation. Population of free living nitrogen fixing bacteria was found to show increase with depth. Other group of microbes showed no distinct gradation with increase in depth (Figure 4a).

During monsoon, organic carbon content and nitrate concentration showed a decreasing trend with increasing depth (Figure 4b). Monsoon played an important role in regulating the microbial population in Sundarban mangrove sediment. During post monsoon, no distinct gradation was found with respect to nutrient conce-tration and organic carbon content of soil along the depth profile. Microbial population showed same profile like nutrient concentration and organic carbon content of soil along the depth profile but only fungal population was found to decrease with increasing depth (Figure 4c).

Annual mean microbial population for rooted region $\left(14.57 \pm 12.42\right.$ C.F.U $\left.\times 10^{6}\right)$ was found relatively higher than un-rooted region $\left(16.29 \pm 6.29\right.$ C.F.U $\left.\times 10^{6}\right)$. The annual range of total microbial population fluctuated to maximum at the un-rooted exposed region $(22.24 \pm 9.46$ C.F.U $\times 10^{6}$ ) and minimum in the deep forest region $\left(15.21 \pm 6.14\right.$ C.F.U $\left.\times 10^{6}\right)$. This indicates the occurrence of relatively stable condition over the deep forest region than that of the other two sites (Figure 5).

In the deep forest region, the most dominating group of microbe was found to be cellulose decomposing bacteria because that region contained more organic carbon content than that of the other two regions. Fungal population was less with respect to the other two regions. It may be attributed to less water content in deep forest region than that of other two regions. Population of SRB also showed more in proportion due to anoxic condition. In rooted region, fungal population was found to be the most dominant. CDB and SRB showed more or less same relative abundance. Population of PSB and free living nitrogen fixing bacteria was more in proportion than population of nitrifying bacteria. In un-rooted region, fungal population was found to be the most dominating group of microbe. The second highest was SRB. Unrooted region was found to retain less organic carbon content for which population of CDB was less than population of fungus and SRB. Un-rooted region is inundated by water in most of the time and it increases water content of soil. More water content caused increase in fungal population. Anoxic condition also created ideal condition for much population of SRB (Figure 6).

Organic carbon content of the soil was found to be most significant on the growth rate of cellulose decomposing bacteria (Pearson correlation of Org.C (\%) and C.D.B. (C.F.U $\times 10^{6}$ ) $=0.500$ P-Value $=0.000$ ). The population of cellulose decomposing bacteria was found to be more in monsoon period than that of pre-monsoon and post monsoon. Again, the zone with more population of phosphate solubilising bacteria showed more concentration of available phosphate. Presence of phosphatase enzyme within such type of bacteria might be responsible for those findings (Cheng and Zhiping, 2007). It might be for availability of more organic carbon source. Rooted region showed a little stratification of nutrients along with microbial population with increasing depth. Rooted region makes the soil perforated for which during high tide nutrients and microbes present in sea water get mixed with soil vertically.

Again the little stratification in that region may be due to absorption of nutrients readily by the roots present in that region. Un-rooted region showed insignificant stratification of nutrient concentration and also for microbial population in those three seasons. That region experiences daily tidal action with great tidal wave and that high energy facilitates to mix the soil vertically (Cyr, 1998). Sulfate reducing bacteria was found to be correlated with sulfate concentration of soil sample (Pearson correlation of Sulfate-Sulfur ( $\mathrm{mg} \mathrm{g}^{-1}$ dry wt of sediment) and S.R.B (C.F.U $\left.\times 10^{6}\right)=0.595$ P-Value $=$ 0.000 ). Phosphate solubilizing bacteria was also found to be correlated with phosphate concentration of the Sundarban mangrove soil (Pearson correlation of phosphate-phosphorous ( $\mu \mathrm{g} \mathrm{g}^{-1}$ dry wt of sediment) and P.S.B $\left(\right.$ C.F.U $\left.\times 10^{6}\right)=0.766$ P-Value $=0.000$ ). No such correlation was found for nitrogen fixing bacteria with nitrate and nitrite concentration.

\section{Conclusion}

From the present study, the following conclusions have 

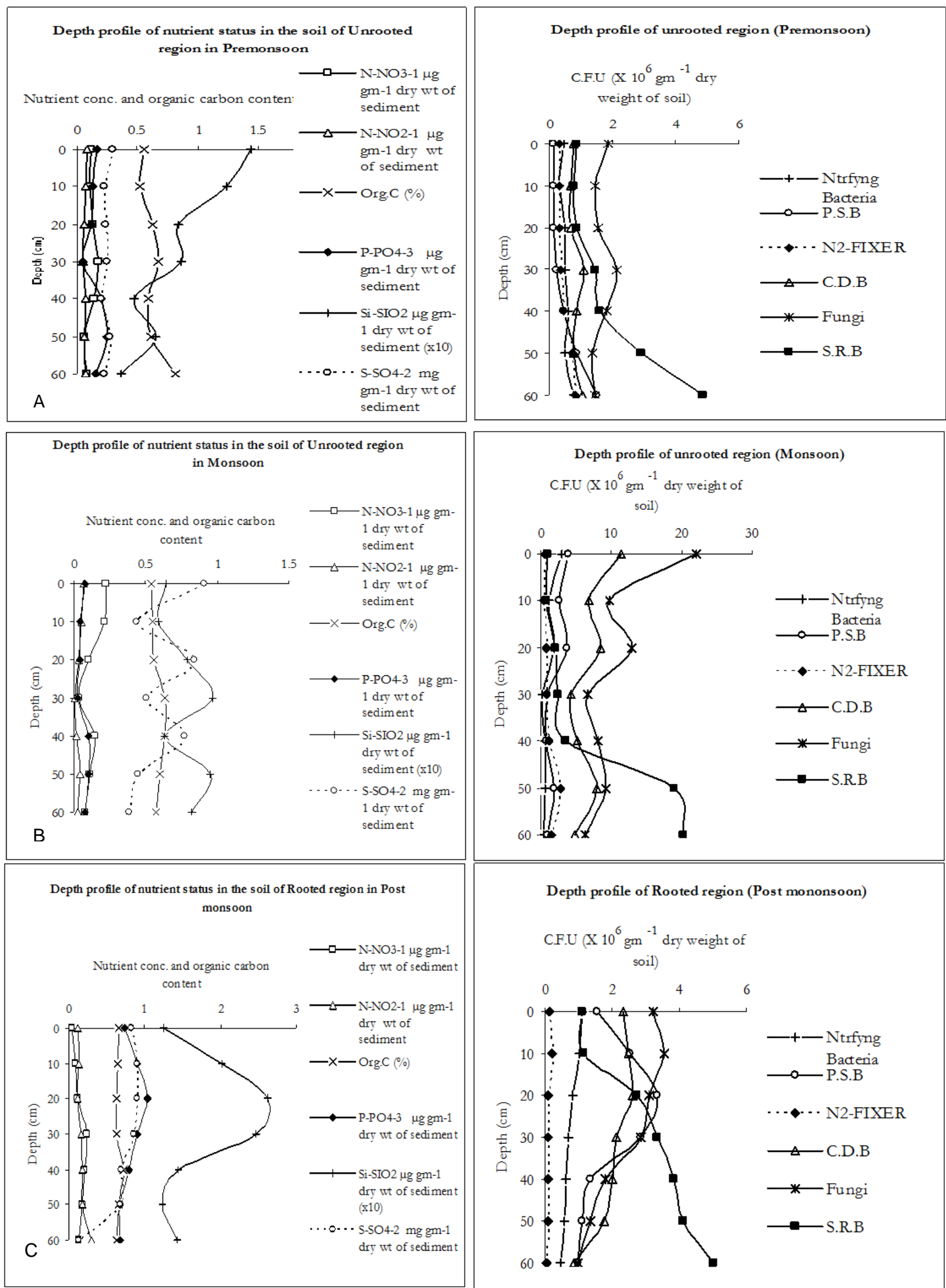

Depth profile of Rooted region (Post mononsoon)

$$
\text { CF.U (X } 10^{6} \mathrm{gm}^{-1} \mathrm{dry} \text { weight of }
$$

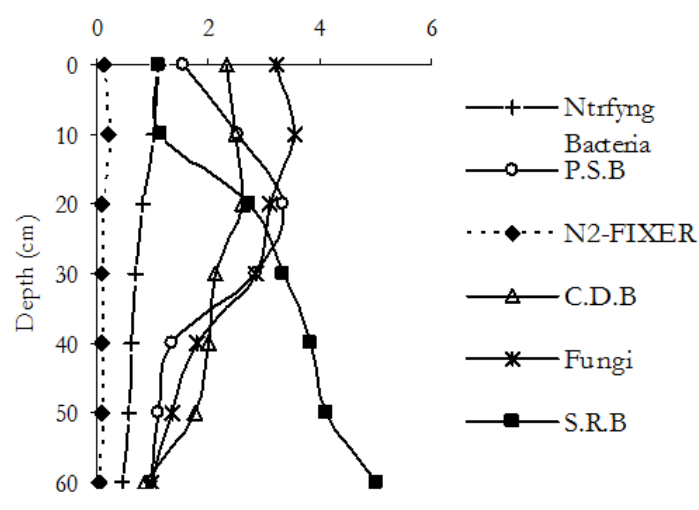

Figure 4. Graphical representation of deep forest region that shows profile of nutrient concentration and CFU of microbes of different category along depth profile during pre monsoon (a), monsoon (b) and post monsoon respectively (c). 

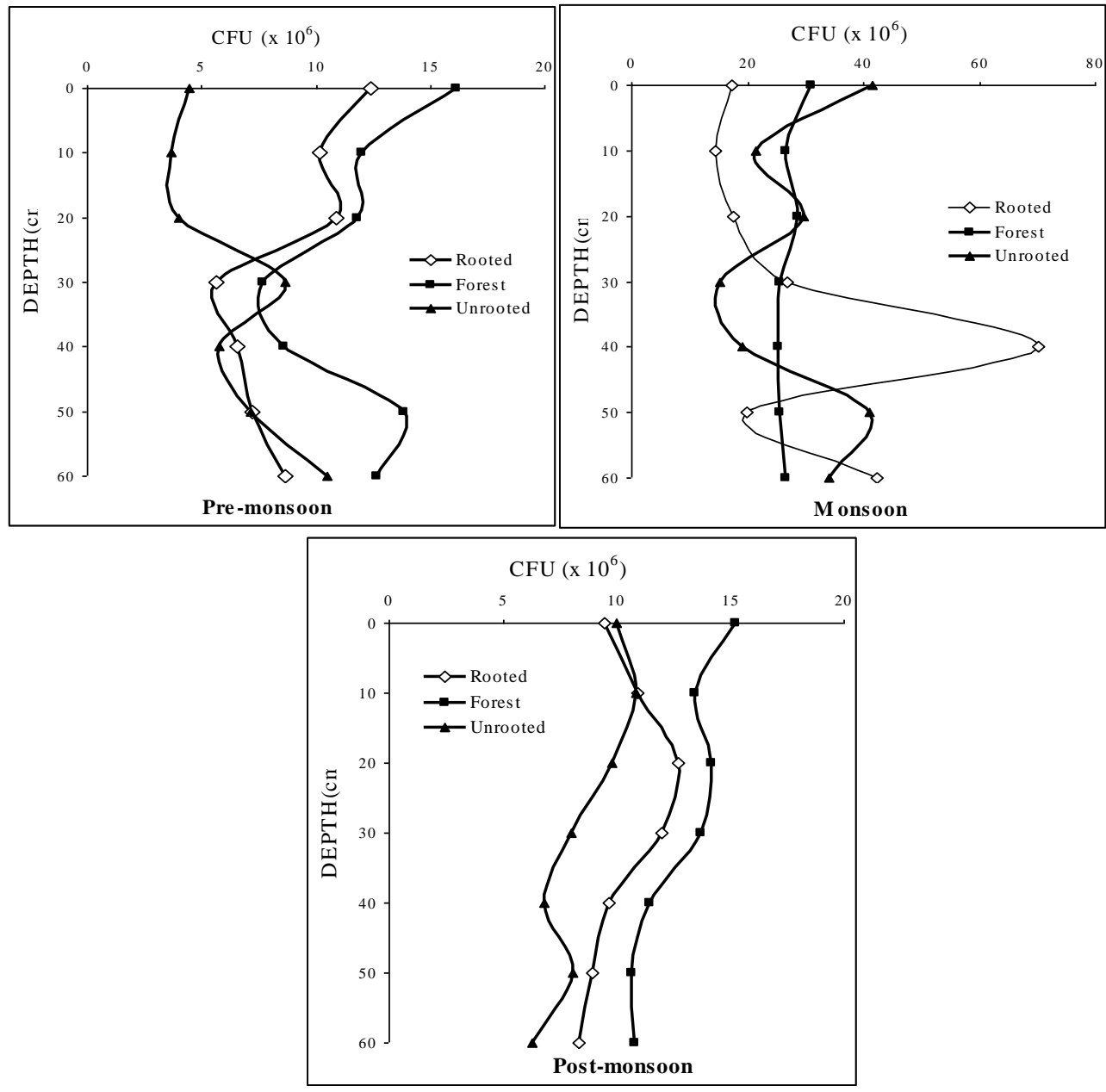

Figure 5. Depth profile of total CFU in 3 different seasons.
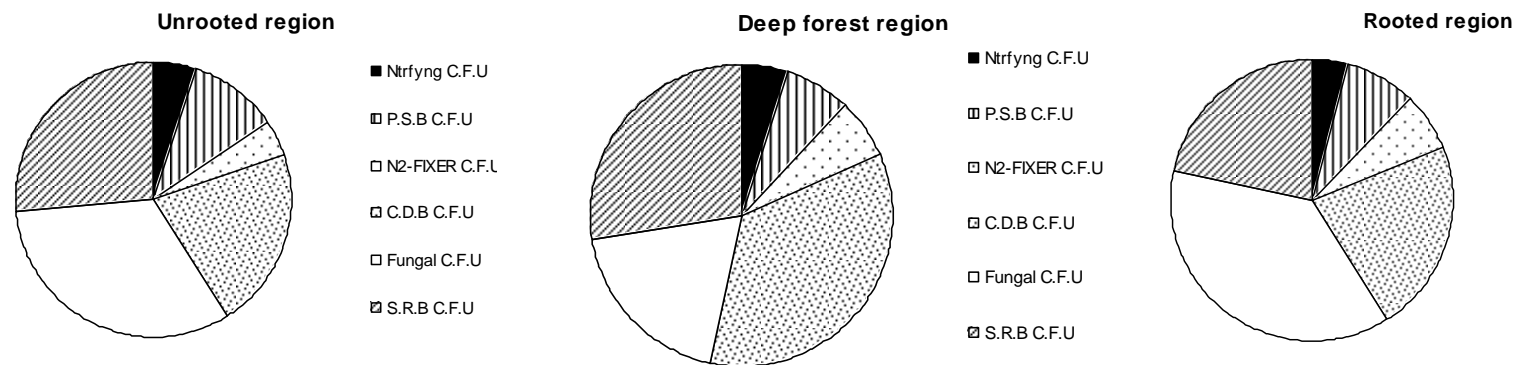

- Ntrfyng C.F.U

口P.S.B C.F.U

口N2-FIXER C.F.U

$\square$ C.D.B C.F.U

口Fungal C.F.U

口S.R.B C.F.U

Figure 6. Relative abundance of microbial population at different site.

been drawn as a result of our research on depth integrated microbial diversity pattern of Sundarban Mangrove forest, along the shore of North East coast of Bay Of Bengal, India:

1) For in deep forest region, a decrease in nutrient con- centration was observed with increase in depth below 30 $\mathrm{cm}$. Active bioturbation could result in vertical mixing of nutrients up to a depth of $30 \mathrm{~cm}$ below which effect of bioturbation become insignificant.

2) The overall concentration of organic $C$ was found more in deep forest region than that of rooted and un-rooted 
region. It might be attributed to undisturbed supply of mangrove litter which converts this zone to most suitable for microbial population.

3) Organic carbon content of the soil was found to be most significant on the population of cellulose decomposing bacteria (Pearson correlation of Organic C $(\%)$ and C.D.B C.F.U $\left(\times 10^{6}\right)=0.500$ P-Value $\left.=0.000\right)$.

4) The zone with higher population of phosphate solubilising bacteria showed more concentration of available phosphate could be attributed to significant activity of phosphatase enzyme (Cheng and Zhiping, 2007). Phosphate solubilizing bacteria was also found to be correlated with phosphate concentration of the Sundarban mangrove soil (Pearson correlation of Phosphate-Phosphorous $\mu \mathrm{g} \mathrm{g}{ }^{-1}$ dry wt of sediment and P.S.B C.F.U $(\times 106)=0.766$ P-Value $=0.000)$. No such correlation was found for nitrogen fixing bacteria with nitrate and nitrite concentration.

Organic carbon from the leaves, wood from forest and other organic dead or waste products from other living creatures are easily degraded by cellulose degrading bacteria in the mangrove sediment because they are the most dominating group of microbes prior to fungi. Other group of microbes also showed significant population which is a good sign for such mangrove forest with respect to mineralization of organic debris and as a result mangrove plants can easily get nutrient in simplest form. It can also be predicted that deep forest region is ecologically more stable than rooted region and unrooted region. Sea level rise due to global warming may hamper the stable ecological zone of Sundarban Mangrove Forest which may ultimately reflect to net flux of several biologically active trace gases between soil and atmosphere.

Introduction of huge amount of nutrients during monsoon have a positive feedback on the bacterial population of mangrove sediment. Beside the changes in several physicochemical parameters, transport of huge amount of aquatic microbes could lead to the significant increase in the microbial population in the sediment of this mangrove ecosystem. This may contribute to the aquatic biogeochemistry of this tropical wetland.

\section{REFERENCES}

Alongi DM (1994). The role of bacteria in nutrient recycling in tropical mangrove and other coastal benthic ecosystems. Hydrobiologia 285:19-32

Alongi DM, Boto KG, Tirendi F (1989). Effect of exported mangrove litter on bacterial productivity and dissolved organic carbon fluxes in adjacent tropical nearshore sediments. Mar. Ecol. Prog. Ser. 56:133144.

Alongi DM, Christofferson P, Tirendi F (1993). The influence of forest type on microbial-nutrient relationship in tropical mangrove sediment. J. Exp. Mar. Biol. Ecol. 171:201-223.

Bharathkumar S, Paul D, Nair S (2008). Microbial diversity of culturable heterotrophs in the rhizosphere of salt marsh grass, Porteresia coarctata (Tateoka) in a mangrove ecosystem. J. Basic Microbiol. 48:10-15.

Brune A, Frenzel P, Cypionka H (2000). Life at the oxic-anoxic interface: microbial activities and adaptations. FEMS Microbiol. Rev. 24(5):691-71.

Chen GC, Tam NFY, Ye Y (2010). Summer fluxes of atmospheric greenhouse gases $\mathrm{N}_{2} \mathrm{O}, \mathrm{CH}_{4}$ and $\mathrm{CO}_{2}$ from mangrove soil in South China. Sci. Total Environ. 408(13):2761-2767.

Cheng H, Zhiping C (2007). Size and activity of the soil microbial biomass and soil enzyme activity in long term field experiments. World J. Agric. Sci. 3(1):63-70

Chen-rul W, Yi S, Xiao-ming Y, Jie W, Jin Y (2003). Advances of study on atmospheric methane oxidation (consumption) in forest soil. $\mathrm{J}$. For. Res. 14(3):230-238.

Cyr H (1998) Effects of wave disturbance and substrate slope on sediment characteristics in the littoral zone of small lakes. Can. J. Fish Aquat. Sci. 55(4):967-976.

Das J, Dangar (2008).TK Microbial population dynamics, especially stress tolerant Bacillus thuringiensis, in partially anaerobic rice field soils during post-harvest period of the Himalayan, island brackish water and coastal habitats of India, World. J. Microbiol. Biotechnol. 24:1403-1410.

Das S, De M, Ray R, Chowdhury C, Jana TK, De TK (2012). Microbial Ecosystem in Sunderban Mangrove Forest Sediment, North-East Coast of Bay of Bengal, India. Geomicrobiol. J. 29:656-666.

Fathul KS, Zaharer I, Adibah Y, Madzlan A (2008) Isolation and Identification of Marine Sulfate Reducing Bacteria Desulfovibrio sp and Citrobacter freundii from Pasir Gudang, Malaysia. Sains Malyasiana 37(4):365-371

Feng $\mathrm{Y}$, Motta AC, Reeves DW, Burmester $\mathrm{CH}$, van Santen E, Osborne JA (2003). Soil microbial communities under conventional-till and notill continuous cotton systems. Soil Biol. Biochem. 35(12):1693-1703.

Ghosh PB, Singh BN, Chakroborty C, Saha A, Das RL, Choudhury A (1990). Mangrove litter production in a tidal creek of Lothian island of Sundarbans, India. Ind. J. Mar. Sci. 19:292-293.

Gonzalez-Acosta B, Bashan Y, Hernandez-Saavedra NY, Ascenaio F, Cruz-Aguero G (2006). Seasonal seawater temperature as the major determinant for populations of culturable bacteria in the sediments of an intact mangrove in an arid region. FEMS Microbiol. Ecol. 55:311 321.

Hayatsu M, Tago K, Saito M (2008). Various players in the nitrogen cycle: Diversity and functions of the microorganisms involved in nitrification and denitrification. Soil Sci. Plant Nutr. 54:33- 45.

Holguin G, Bashan Y, Vazavez P (2001). The role of sediment microorganism in the productivity, conservation and rehabilitation of mangrove ecosystem: An Overview. Biol. Fertil. Soils 33:265-278.

Kristensen E, Bouillon S, Dittmar T, Marchand C (2008). Organic carbon dynamics in mangrove ecosystems: A review. Aquat. Bot. 89: 201-219.

Laing GD, Rinklebe J , Vandecasteele B , Meers E , Tack FMG (2009). Trace metal behaviour in estuarine and riverine floodplain soils and sediments: A review. Sci. Total Environ. 407: 3972-3985.

Liebner S, Rublack K, Stuehrmann T, Wagner D (2008). Diversity of Aerobic Methanotrophic Bacteria in a Permafrost Active Layer Soil of the Lena Delta, Siberia. Microb. Ecol. 57:25-35.

Lovley DR, Klug MJ (1982). Intermediary metabolism of organic matter in the sediment of a eutrophic lake. Appl. Environ. Microbiol. 43:552560 .

Mohanraju R, Natarajan R (1992). Methanogenic bacteria in mangrove sediments. Hydrobiologia 247: 187-193.

Nicol WG, Leininger S, Schleper C, IP James (2008). The influence of soil $\mathrm{pH}$ on the diversity, abundance and transcriptional activity of ammonia oxidizing archaea and bacteria. Environ. Microbiol. 10(11):2966-2978.

Radhakrishnan M, Saravanan D, Balagurunathan R, Vanaja K (2011). Fungal Bioproespecting from Sundarban Mangrove Forest with special reference to Antibacterial and Antimycobacterial Activity. Int. J. PharmTech Res. 3(2):719-723.

Ramanathan AL, Singh G, Majumder J, Samal AC, Chowhan R, Rayan RK, Roykumar K, Santra SC (2008). A study of microbial diversity and its interaction with nutrients in the sediments of Sundarban mangroves. Indian J. Mar. Sci. 37(2):159-165.

Riley RH, Peter M, Vitousek PM (1995), Nutrient dynamics and nitrogen trace gas flux during ecosystem development in montane rain forest, Ecology 76(1):292-304. 
Rojas A, Holguin G, Glick BR, Bashan Y (2001). Synergism between Phyllobacterium sp. ( $\mathrm{N}_{2}$-fixer) and Bacillus licheniformis (Psolubilizer), both from a semiarid mangrove rhizosphere. FEMS Microbiol. Ecol. 35:181-187.

Sahoo K, Dhal NK (2009). Potential microbial diversity in mangrove ecosystem: A review. Indian J. Mar. Sci. 38(2):249-256.

Sass H, Cypionka H, Babenzien H-D (1997). Vertical distribution of sulfate-reducing bacteria at the oxic-anoxic interface in sediments of the oligotrophic Lake Stechlin. FEMS Microbiol. Ecol. 22(3):245-255.

Senior E, Lindstrom EB, Banat IM, Nedwell DB (1982). Sulfate reduction and mathanogenesis in the sediment of a saltmarsh on the eastcoast of the United Kingdom. Appl. Environ. Microbiol. 43:987996.

Teri CB, Mary KF (2005). Linking microbial community composition and soil processes in a California annual grassland and mixed conifer forest. Biogeochemistry 73(2):395-415.
Thatoi H, Chandra BB, Kanti DT, Ranjan MR (2012). Microbial Biodiversity in Mangrove soils of Bhitarkanika, Odisha, India. Int. J. Environ. Biol. 2012; 2(2): 50-58.

Tiwari SC, Tiwari BK, Mishra RR (1989). Microbial community, enzyme activity and $\mathrm{CO}_{2}$ evolution in Pineapple Orchard soil. Trop. Ecol. 30(2):265-273.

Vazquez P, Holguin G, Puente ME, Lopez-Cortes A, Bashan Y (2000). Phosphate-solubilizing microorganisms associated with the rhizosphere of mangroves in a semiarid coastal lagoon. Biol. Fertil. Soils 30:460-468.

Zemin Q, Kaiyun W, Yuanbin Z (2010). Quantitative Property of Different Soil Bacterial Physiological Groups in Subalpine Timberline Ecotone and Adjacent Vegetations in Western Sichuan. Scientia Silvae Sinicae 46(2):12-18. 